$$
\begin{aligned}
& \text { 克 음 }
\end{aligned}
$$

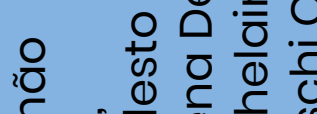

$$
\begin{aligned}
& \text { ค }
\end{aligned}
$$

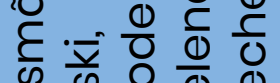

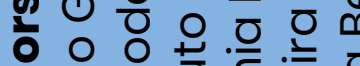

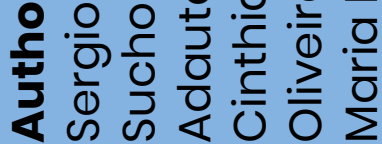

\title{
From global to local: \\ subnational development banks in the era of Sustainable Development Goals
}
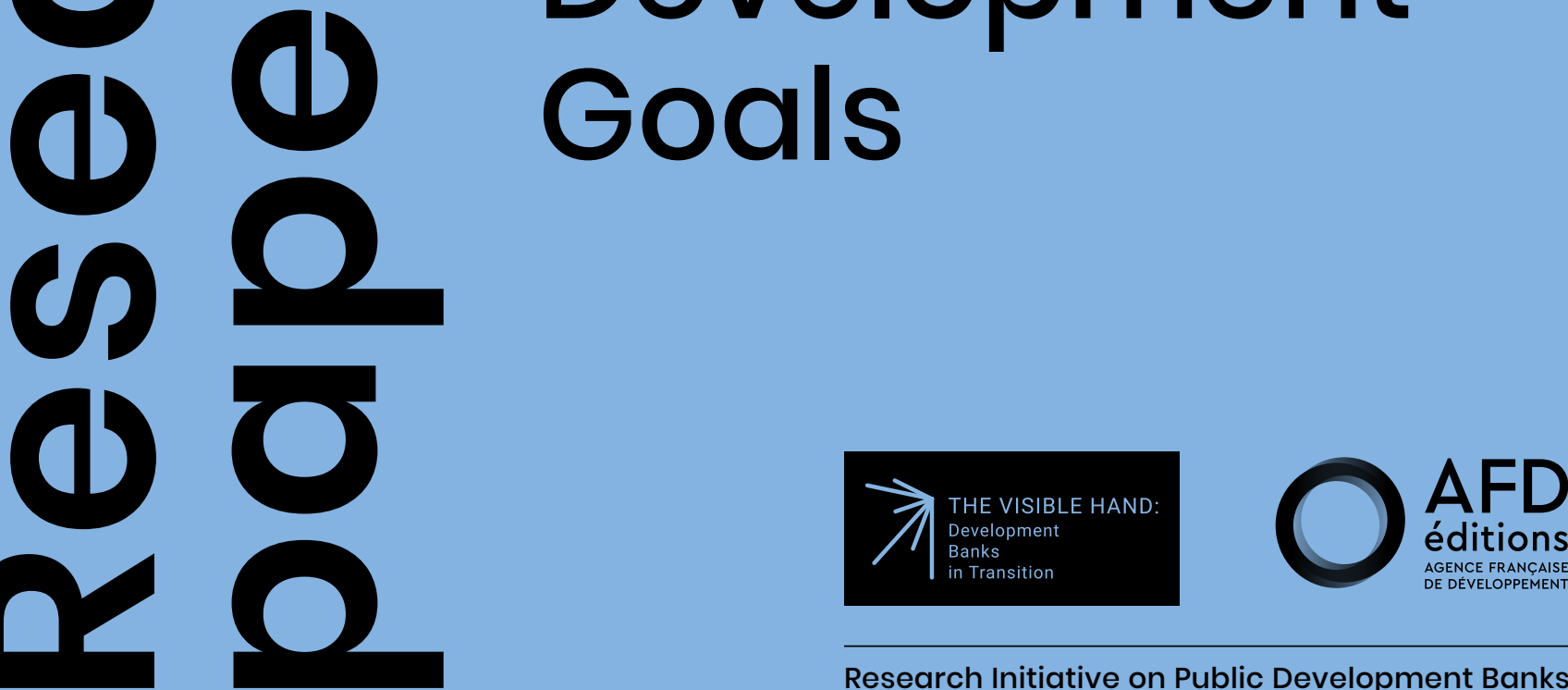


\section{About the research program}

This paper is published in the framework of the International Research Initiative on Public Development Banks (PDBs) working groups, part of the research program: "Realizing the Potential of Public Development Banks for Achieving Sustainable Development Goals".

This research program aims to deliver concrete policy recommendations to decision-makers on how to scale up Public Development Banks' potential at achieving the Sustainable Development Goals (SDGs). The academic research focuses on five major themes:

- Characterization of SDG-compatible investments

- Business Models

- Governance

- Financial regulation

- Global Development Finance Architecture

\section{Partners and coordinators}

This research program was launched by the Institute of New Structural Economics (INSE) at Peking University, and sponsored by the Agence Française de Développement (AFD), Ford Foundation and International Development Finance Club (IDFC). It is coordinated by Jiajun Xu, Executive Deputy Dean at the Institute of New Structural Economics (INSE) at Peking University; Stephany Griffith-Jones, Initiative for Policy Dialogue, Columbia University; and Régis Marodon, Special Adviser on Sustainable Finance at the Agence française de développement (AFD).

The research program's working groups first presented their works and findings during the Academic Days of the $14^{\text {th }}$ AFD International Research Conference on Development, The Visible Hand: Development Banks in Transition, on the occasion of the Finance in Common Summit in November 2020. These Academic Days were co-organized by INSE and AFD.

All the information about this program, and all working papers published are available at: www. afd.fr/en/carte-des-projets/realizing-potentialpublic-development-banks-achievingsustainable-development-goals 


\section{Agence française de développement}

\section{Papiers de recherche}

Les Papiers de Recherche de l'AFD ont pour but de diffuser rapidement les résultats de travaux en cours. Ils s'adressent principalement aux chercheurs, aux étudiants et au monde académique. Ils couvrent l'ensemble des sujets de travail de l'AFD : analyse économique, théorie économique, analyse des politiques publiques, sciences de l'ingénieur, sociologie, géographie et anthropologie. Une publication dans les Papiers de Recherche de l'AFD n'en exclut aucune autre.

Les opinions exprimées dans ce papier sont celles de son (ses) auteur(s) et ne reflètent pas nécessairement celles de l'AFD. Ce document est publié sous l'entière responsabilité de son (ses) auteur(s).

\author{
AFD Research Papers \\ AFD Research Papers are intended to rapidly \\ disseminate findings of ongoing work and mainly \\ target researchers, students and the wider \\ academic community. They cover the full range \\ of AFD work, including: economic analysis, economic \\ theory, policy analysis, engineering sciences, \\ sociology, geography and anthropology. AFD \\ Research Papers and other publications are not \\ mutually exclusive. \\ The opinions expressed in this paper are those \\ of the author(s) and do not necessarily reflect \\ the position of AFD. It is therefore published under \\ the sole responsibility of its author(s).
}


From global to local: subnational development banks in the era of Sustainable Development Goals

Sergio Gusmão Suchodolski Development Bank of Minas Gerais, Belo Horizonte, Brazil

Adquto Modesto Junior

Development Bank of Minas

Gerais, Belo Horizonte, Brazil

\section{Cinthia Helena De Oliveira} Bechelaine

Development Bank of Minas

Gerais, Belo Horizonte, Brazil

Leila Maria Bedeschi Costa

Development Bank of Minas

Gerais, Belo Horizonte, Brazil

\section{Abstract}

Financing the implementation of the seventeen Sustainable Development Goals (SDGs) has been a development challenge since the establishment of the 2030 Agenda - especially under the unequal circumstances imposed by COVID-19. This paper aims to better inform this debate by highlighting the nature of Subnational Development Banks (SDBs) in the context of sustainable finance and how they operate within development networks. To this end, the research method used addresses a comparative study among countries that stand out for the number of subnational institutions in their development systems, Brazil and Vietnam. After comparing the Brazilian and Vietnamese particularities, we present concrete examples of SDBs working to connect local needs to the 2030 Agenda investments. As final conclusions, the study allows to demonstrate that, by being the last mile specialist on the ground, in different localities, with particular backgrounds and contexts, SDBs could be available channels to international resources to address financial needs of local firms and governments, improving both efficiency and effectiveness of development programs and funds. Highlighting the potential of SDBs, this analysis leaves possibilities for a future research agenda on more integrated national development finance systems focused on local impact.

\section{Keywords}

Subnational Development Banks, Brazil, Vietnam, Impact, SDGs

\section{Acknowledgements}

This research project is part of an initiative to expand the study on Development Banks at the subnational level. The authors are thankful to Stephany Griffith-Jones, Regis Marodon, Jiajun Xu and Barbara Oliveira for their great support.

\section{JEL Classification}

F36, G21, H7, RII

\section{Original version \\ English}

\section{Accepted}

October 2020

\section{Résumé}

Le financement pour mise en œuvre des dix-sept Objectifs de Développement Durable (ODD) est un défi du développement depuis la mise en place de l'Agenda 2030 - en particulier dans les circonstances inégales imposées par le COVID-19. Cet article vise à mieux éclairer ce débat en mettant en évidence la nature des Banques de Développement Territoriale (BDT) dans le contexte de la finance durable et leur fonctionnement au sein des réseaux du développement. À cette fin, la méthode de recherche utilisée est basée sur une étude comparative entre les pays qui se distinguent par le nombre d'institutions publiques territoriales dans leurs systèmes de développement, au Brésil et au Vietnam. Après comparer les particularités brésiliennes et vietnamiennes, nous présentons des exemples concrets de BDT travaillant à connecter les besoins locaux aux investissements de I'Agenda 2030. En guise de conclusion, l'étude permet de démontrer qu'en étant un grand spécialiste de sa propre région, avec des antécédents et des contextes particuliers, les BDT pourraient être les canaux disponibles vers des ressources internationales pour répondre aux besoins financiers des entreprises et des gouvernements locaux de maniérer l'efficiente et l'efficace des programmes et des fonds de développement. Soulignant le potentiel des BDT, cette analyse laisse des possibilités des nouvelles recherches sur les systèmes nationaux de financement du développement plus intégrés et ciblés sur l'impact local.

\section{Mots-clés}

Banques de développement infranationales, Brésil, Vietnam, Impact, ODD 


\section{Introduction}

Multilateral and national development banks have been widely discussed in the literature since the iconic Bretton Woods meeting in 1944. The role of such institutions in financing long-term investments (Diamond, 1957; Bruck, 2001), correcting market failures (Stiglitz, 1994; Levy-Yeyati, Micco and Panizza, 2004), acting in a countercyclical manner in global financial crisis (Brei and Schclarek, 2013; 2018) and performing as a strategic player for governments (La Porta, LopezDe-Silanes and Shleifer, 2002; Mazzucato and Penna, 2014), has been the subject of several discussions for over 75 years. However, little academic research has been carried out around the last mile institutions on the development scale: the Subnational Development Banks (SDBs) - which undermines the capacity of scholars and public officials to fully understand and explore their potential to contribute to Sustainable Development Goals (SDG) implementation, specially under the challenging conditions imposed by COVID-19.

Alongside the discussion of development banks on the subnational level, the debate on sustainable development, increasingly pressing after the 2015 international agreements, requires an unprecedented change in the volume of investments, in the type of offer and in business models for both public and private sectors. In that regard, GriffithJones and authors (2018) points out the importance of development banks as institutional vehicles to support the urgency of major investment in sustainable development and consequently the need for a structural transformation in the development model. Yet, besides the international finance flows that are being focused on the sustainable frontier, the challenge remains greater for the less developed regions of the planet. The needs are still more demanding when it comes to underdeveloped regions facing a combination of high levels of income inequality, high poverty ratios and climate-related vulnerabilities. To this end, the claiming lies in how to ensure that sustainable finance available in the international market will be applied according to the needs of local population in less developed regions.

This paper aims to better inform this debate by highlighting the nature of SDBs in the context of sustainable finance and how they operate within development networks. Questions such as: what are they, how many and where they are, how do they build their role, and how do they relate to governments and other banking institutions at regional, national, and global levels, will be explored. In order to fulfill this objective, the research method applied a comparative study among countries that stand out for the number of subnational institutions in their development systems, Brazil and Vietnam. After comparing the Brazilian and Vietnamese cases, we present concrete examples of SDBs working to connect local needs to the 2030 Agenda. These real cases studies strengthen the argument of how SDBs can act as key actors in directing international capital to finance local development impact and may present useful insights for other contexts. 
The research is divided into six parts. The first section explores the subnational development banks worldwide, differentiating them from national and multilateral institutions and also placing how many there are, when they were founded and where. The second and third sections present the Brazilian and the Vietnamese SDBs, discussing the main characteristics and peculiarities of each development system. The differences and similarities of these two systems are presented in a comparative chart in the fourth section. Section five focus on how SDBs have been working at the local level to address the financing demands connected with the SDGs with real examples of institutions from Brazil and Vietnam. Finally, the final conclusions of this work are presented in section six.

\section{I - Subnational Development Banks worldwide: who and where are they}

According to their ownership, $\mathrm{Xu}$, Ren and Wu (2019) divide development banks into two groups, as shown in the Figure 1 . The first, belonging to more than one country, constitutes the group of Multilateral Development Banks (MDBs) at the regional or global levels. The second group are those created by a country or a region of a country, establishing the National Development Banks (NDBs) and the Subnational Development Banks (SDBs), respectively.

Figure 1: Category of development finance institutions by ownership

Source: Authors elaboration adapted from Xu, Ren and Wu, 2019.

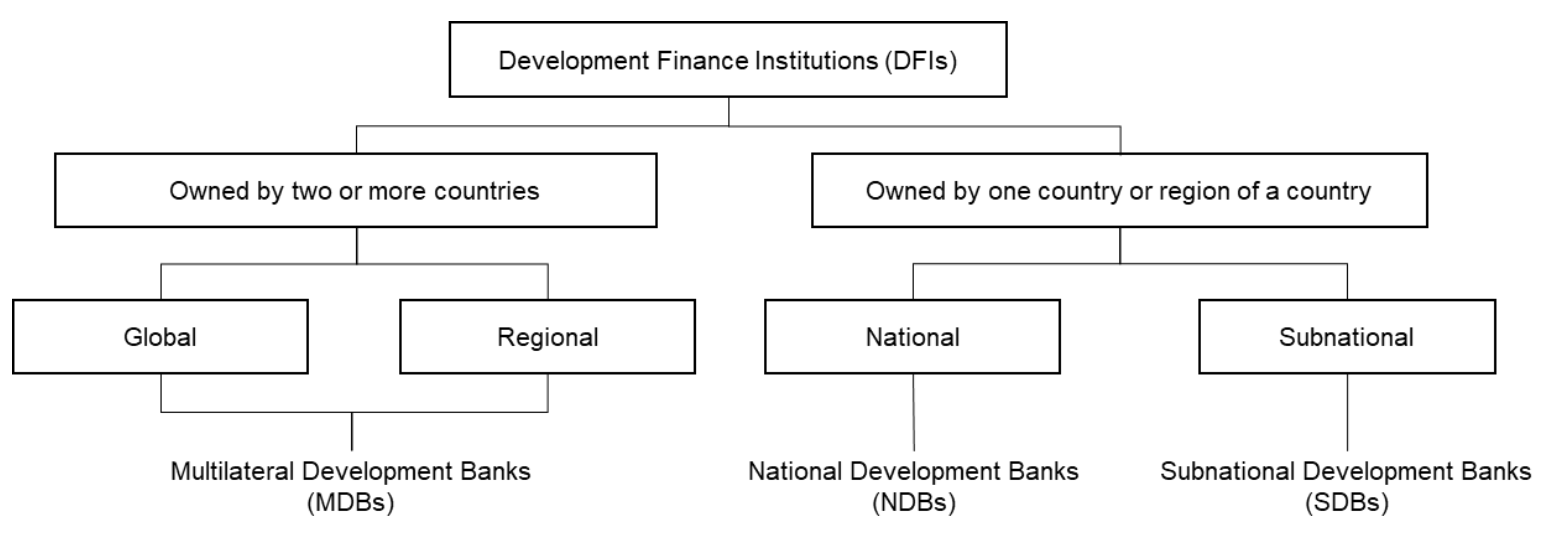


The MDBs make up the core of the system designed to finance investments that promote economic growth and social development worldwide (Shelepov, 2017). According to Xu, Ren and Wu (2019), multilateral organizations are established by two or more countries and can be divided into global institutions, with global members (without distinguishing between regional and non-regional members), regional institutions, consisting of groups of countries from one or more regions.

Unlike multilateral ones, in which equity participation may vary between a set of countries with different levels of participation, a constitutive feature of NDBs is the participation of one national state, as the name suggests. As detailed by De Luna-Martinez and Vicente (2012), NDBs are essentially institutions owned, administered and controlled by the government of a nation, which must provide strategic direction and assign members of the board. According to a survey conducted by the World Bank on NDBs, about $75 \%$ of the institutions surveyed have $100 \%$ state ownership (De Luna-Martinez and Vicente, 2012). In addition to government ownership, Griffith-Jones and authors (2018) points out the considerable number of institutions around the world and their large-scale operations of NDBs. In terms of total assets, Studart and Gallagher (2016), when distinguishing more than 250 NDBs with at least US\$ 5 trillion in assets in 2015, point out that many NDBs surpass multilateral banks in size, scale and scope.

The predominant characteristic of SDBs, on the other hand, is the performance within a country, whether at the regional, state/provincial, or even local level. Although many academic articles have discussed how development institutions can be effective at the multilateral and national levels, SDBs are still little explored in academic research in the field of development finance.

The reason for going subnational in the establishment of public financial institutions is related to the belief that the combination of national and subnational development policies would lead to improved results in comparison to those achievable only with national ones (Ferroni, 2004). In other words, by better knowing and monitoring the needs and peculiarities of their regions, SDBs would tend to act with greater selectivity e effectiveness, favouring local financing and, therefore, driving development in their territories. Another argument that advocates the institution of SDBs is that provincial or local public banks may increase regional welfare as they prevent a capital drain from poorer to richer regions by financing local projects and creditors in a more integrated economy (Hakenes and Schnabel, 2010).

As difficult as can be to determine the exact number of development banks around the world, the French Development Agency (AFD), in a notorious effort to fulfil the data gap, mapped 447 institutions at the multilateral, national or subnational levels in 2020 . About $76 \%$ of institutions are national or subnational development banks around the world. More exactly, 15\%, or 66 institutions, represents SDBs in the last mile development scale. 


\section{Figure 2: DFIs by Ownership}

Source: Authors elaboration from AFD database.

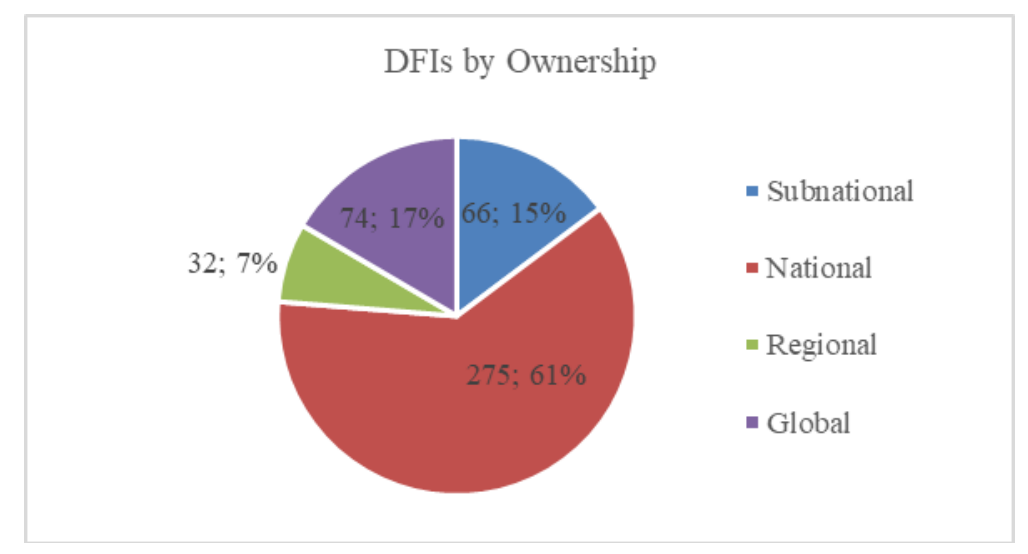

Comparing these institutions in terms of total assets, NDBs appear as outliers. In fact, GriffithJones and authors (2018) points out as a characteristic of NDBs the considerable number of institutions around the world and the large-scale performance. In terms of total assets, Studart and Gallagher (2016), when distinguishing more than 250 NDBs with at least US \$ 5 trillion in assets in 2015, point out that many NDBs surpass multilateral banks in size, scale and scope. According to AFD data, as shown in Figure 3, approximately $74 \%$ of assets are concentrated at the national level, with nearly USD 7.7 trillion in assets. MDBs concentrate $23 \%$ of total assets, with $17 \%$ at the global level. Subnational banks account for $3 \%$ of total assets, with around USD 300 billion in assets?

\section{Figure 3: DFIs by Assets (Bis USD)}

Source: Authors elaboration from AFD database.

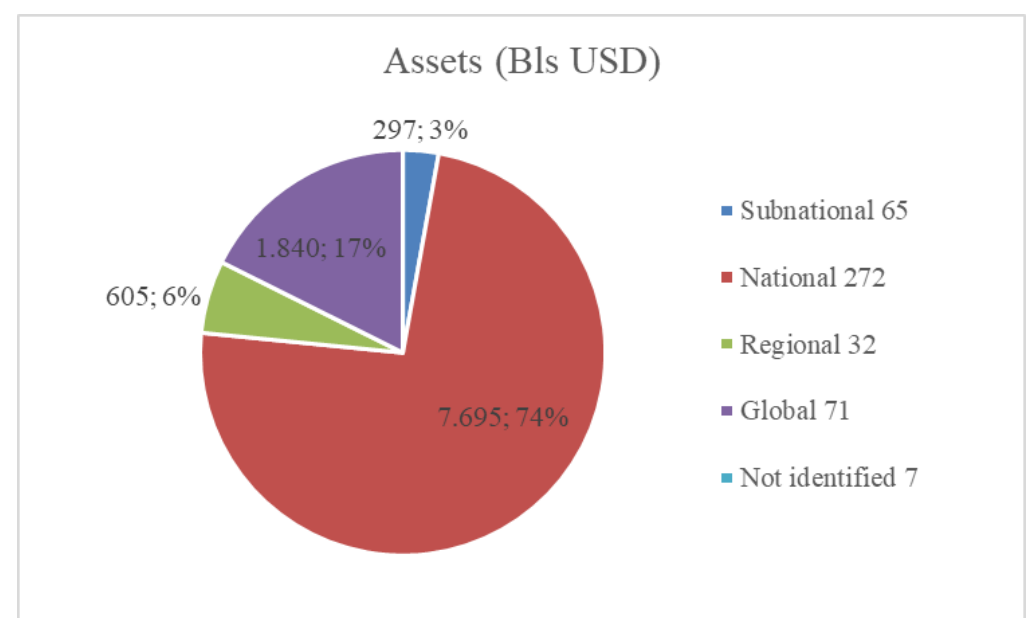

1 It is important to highlight that the SDB's total assets number does not fully capture its relative importance since most of them operates as second-tier banks implementing on-lending programs from larger NDB and/or Multilateral ones. 
The golden age of NDBs began in the 1950s, when countries from different regions sought a rapid industrialization, as mentioned by Griffith-Jones and authors (2018) and Torres and Zeidan (2016). Compared to NDBs, however, the establishment of SDBs are more recently. Only $6 \%$ were founded before the Second World War, such as Banco Ciudad de Buenos Aires in Argentina (1878), Investitionsbank and Landersbank Saar in Germany (1924 and 1941), and Bank of North Dakota in the USA (1919). Another 17\% were created between 1945-1979, including the Brazilian development banks Bank of Northeast (Banco do Nordeste do Brasil - BNB), South Regional Development Bank (Banco Regional de Desenvolvimento do Extremo Sul $\mathrm{BRDE}$ ), both at regional level, and the Development Bank of Minas Gerais (Banco de Desenvolvimento de Minas Gerais - BDMG) at state level, and the Colombian Instituto para el Desarrollo de Antioquia (IDEA). 20\% of SDBs were established between 1980 and 1999, a period marked by a massive process of public banks privatization in many parts of the world. Examples of SDBs established during this period include the Catalan Institute of Finance (ICF) in Spain (1985), the California Infrastructure and Economic Development Bank (IBank) in the USA, and the Brazilian development agencies, as discussed in the next section.

The bulk of SDB's ( $56 \%$ of them) were established after 2000, both in developing countries and countries with sophisticated financial systems. Examples of SDBs in developing countries include Vietnamize local funds and Brazilian development agencies. New institutions in developed countries such as USA, Germany, United Kingdom and France were funded with a specific focus to provide infrastructure finance or help mitigate climate change challenges. Examples of specific SDBs in the USA include the Connecticut Green Bank (2011), the NY Green Bank and the Hawaii Green Infrastructure Authority, both funded in 2014.

Figure 4: Period of establishment of SDBs

Source: Authors elaboration from AFD database.

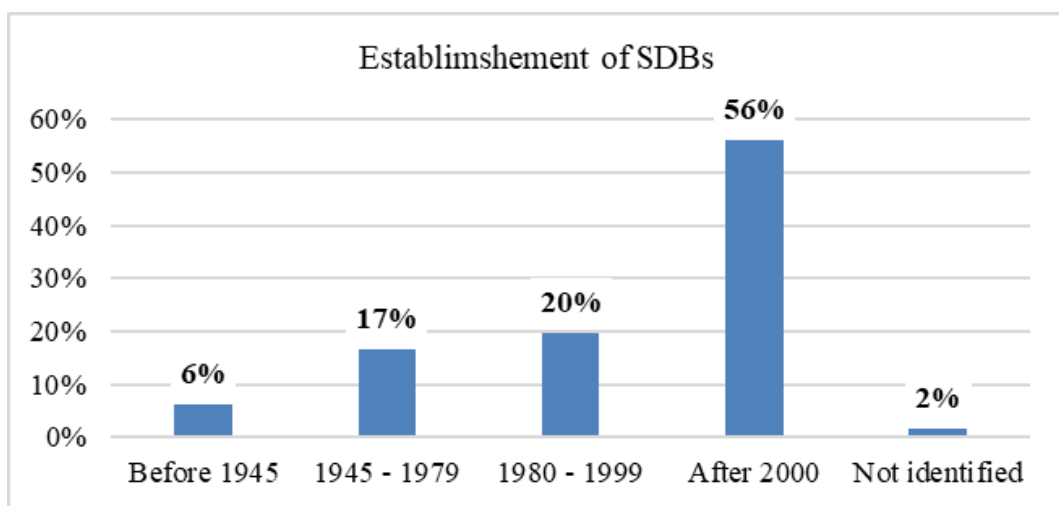

Among SDBs mapped, $32 \%$ are located at South America - where Brazil stands out; $29 \%$ in Asia - particularly in Vietnam who has 18 institutions; 23\% in Europe, especially in Italy and Germany; and the last 17\% in North America and Pacific (Figure 5). According to Xu, Ren and $\mathrm{Wu}$ (2019), the number of institutions in countries with different income levels corresponds to an inverted $U$ shape: on average, middle-income economies have more development financial institutions than high and low-income economies. 


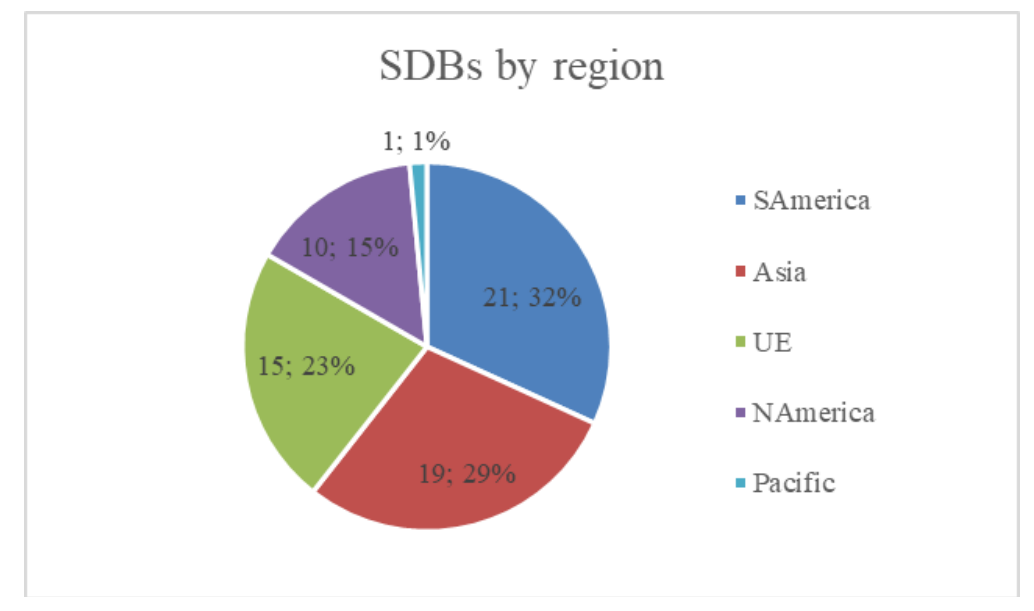

Because of the complexity of their systems of SDBs and the active role that these institutions play in the implementation of development agendas within their countries, the examples of Brazil and Vietnam will be further explored in the next two sections, in which we try to describe both systems, compare similarities and differences and draw lessons that might be applicable to other contexts.

\section{II - Brazilian Subnational Development Banks: boom, shrinking and current outlook}

Brazil is a federative republic, composed by states with a certain degree of autonomy (selfgovernment, self-regulation and self-collection) and capable with their own government and constitution. There are 26 states, that are divided into municipalities, and one federal district. The regional or subnational economies differ from one another in several ways, with particularities in history background and development indexes, including access to credit.

The foundation of National Bank for Economic and Social Development (BNDES), in 1952, was the main milestone for the creation of the regional or state financial development institutions (Horn and Feil, 2019). Brazilian SDBs originated by the developmentalist approach in the 1950s integrate, together with the BNDES, the so-called National Development System (SNF) (Araújo et al., 2013; Cunha, Prates and Carvalho, 2016). The SNF constitutes a system of financial institutions controlled by the federal government, states, or groups of states. 
According to Araújo et al. (2013), the regional or state public development banks, the SDBs, were created to act in a complementary way to the BNDES, establishing themselves, at the time, as important sources of credit for the regional economy and financial inclusion of sectors without access to credit in the traditional banking market (Ferraz and Ramos, 2018). To Horn and Feil (2019), the SDBs can help break the vicious circle in which the credit supply tends to go to regions that have a higher degree of economic development, encouraging the access to local credit and increasing the capillarity of the Brazilian financial system.

The 1950s and the 1960s saw the creation of several SDBs, as stated by Araújo and authors (2013). Along with the creation of the BNDES, in 1952, the Banco do Nordeste (BNB), the bank of the northeast region of Brazil, was created, and later in 1966, the Bank of the Amazon region (Banco da Amazônia - BASA) was funded. As stated by Horn and Feil (2019), the creation of FINAME (Special Industrial Financing Agency) in 1966, following the expansion of BNDES activities, boosted the creation of development banks in the states, which started to act as resource transfer agents, expanding the capillarity of the national bank (Cavalcante, 2007). By 1970, four states already had their own development bank: Minas Gerais (1962), Bahia (1966), Paraná (1968) and Espírito Santo (1969), in addition to another regional bank combining three states of the southern region (Rio Grande do Sul, Santa Catarina and Paraná) - the BRDE founded in 1962. From 1970, eight other states would also follow the same trend, with the creation of development banks of Maranhão, Ceará, São Paulo, Rio Grande do Norte, Rio Grande do Sul, Rio de Janeiro, Goiás and Santa Catarina.

According to Salviano Junior (2004), the growth of the state financial system would reach its peak in 1988, when state banks, development banks and state savings banks accounted for $10 \%$ of banking system assets and deposits, for $17 \%$ of operations and $6 \%$ of the banks 'total shareholders' equity.

However, the trajectory of state banks has undergone several transformations until the current configuration. Changes caused by financial crises, problems of governance and internal management in banks would imply a shrinking of institutions (UN-DESA, 2005), especially the state financial institutions affected by the 1980 crisis (Araújo et al., 2013).

From the 1990s onwards, in the context of market-oriented reforms, the Brazilian Program for the Reduction of the Public Sector's Presence in Banking Activity (Programa de Incentivo à Redução do Setor Público Estadual na Atividade Bancária - PROES) was launched in 1996, with the objective of prepare state and development banks for privatization purposes (Salviano Junior, 2004). The structure of the system has changed dramatically. According to Gama Neto (2011), PROES was seen as one of the solutions to the constant financial crises of state banks and an important contribution to the efforts to reduce inflation at the time. The controlling states of the banks could opt for their subsequent privatization, extinction or transformation into Development Agencies (DAs) (Cunha, Prates and Carvalho, 2016). This re-configuration of the Brazilian development system through the privatization of commercial banks under public control and the transformation of development banks into DAs was based on the premise of greater control over the level of states indebtedness and less exposure to popular savings, without detracting the importance of its socioeconomic role. 
After the PROES, sixteen development agencies were created. According to Araújo and authors (2013), as non-financial institutions regulated by the Brazilian Central Bank (BACEN), they represented an alternative offered to states that had lost their development banks. Although they still have the same objectives and are regulated as development banks, DAs differ from banking institutions as they cannot: (i) raise funds from the public; (ii) have a reserve account at the Brazilian Central Bank and (iii) contract interbank deposits as depositors or depositaries. They operate through equity capital and on-lending funds (as BNDES) from national and international development organizations (Araújo et al., 2013). They are also obliged to establish and maintain, permanently, a liquidity fund equivalent to at least $10 \%$ of the value of its obligations, which must be fully invested in federal public securities (Horn and Feil, 2019). The three development banks that remained after the execution of PROES, correspond to two state banks - Minas Gerais (BDMG) and Espírito Santo (BANDES), and the regional bank in the southern region (BRDE). Such institutions are essentially controlled by government states and have as their main characteristic the responsibility to grant credits, especially in the medium and long term, aiming at the economic and social development of the region where they operate. Its liabilities consist of long-term deposits, foreign loans, bonds and government transfers.

And there are also the two multiple banks created by the federal government with regional coverage: the Northeast Regional Bank (BNB) and the Amazon Bank (BASA). Multiple banks in Brazil have as their main characteristic the existence of diversified portfolios, such as commercial, investment and/or development, leasing and credit, financing and investment. Unlike development banks, its liabilities include direct deposits.

Figure 6: SDBs in Brazil

Source: Authors elaboration from Central Bank of Brazil, 2019.




In a longitudinal analysis using data from Brazil's Central Bank, after the implementation of PROES, when there were 13 SDBs, the total assets corresponded to BRL 15.7 billion in the year 2000. By 2011, another 8 development agencies were created in the state level, and in 2019 , the total assets of the 21 SDBs correspond to BRL 113.4 billion. The growth of assets is more than $600 \%$ in the 20 years analysed, an average growth of about $11 \%$ per year, as shown in the Figure 7.

Comparing the total assets growth of SDBs with BNDES's assets, it is possible to verify some variations. In the 2000s, the total assets of the SDBs corresponded of $16 \%$ of BNDES total assets. From 2007 to 2015, there was a noticeable growth in the BNDES total assets, distancing the NDB from the group of SDBs currently existing. Part of this growth is due to the Investment Support Program (Programa de Sustentação do Investimento - PSI), responsible for making financing conditions more attractive for the acquisition of machinery and equipment produced in Brazil in an economic retraction context. In this period, the ratio of total SDB assets to BNDES assets corresponded to around $9 \%$, even with the increase in the number of development agencies. From 2015, with the decrease in BNDES assets and parallel growth in SDB assets, the SDBs assets return to the level of approximately $15 \%$ of the NDB assets.

Figure 7: Total assets per year BNDES and SDBs in Brazil 2000-2019

Source: Authors elaboration from Central Bank of Brazil database.

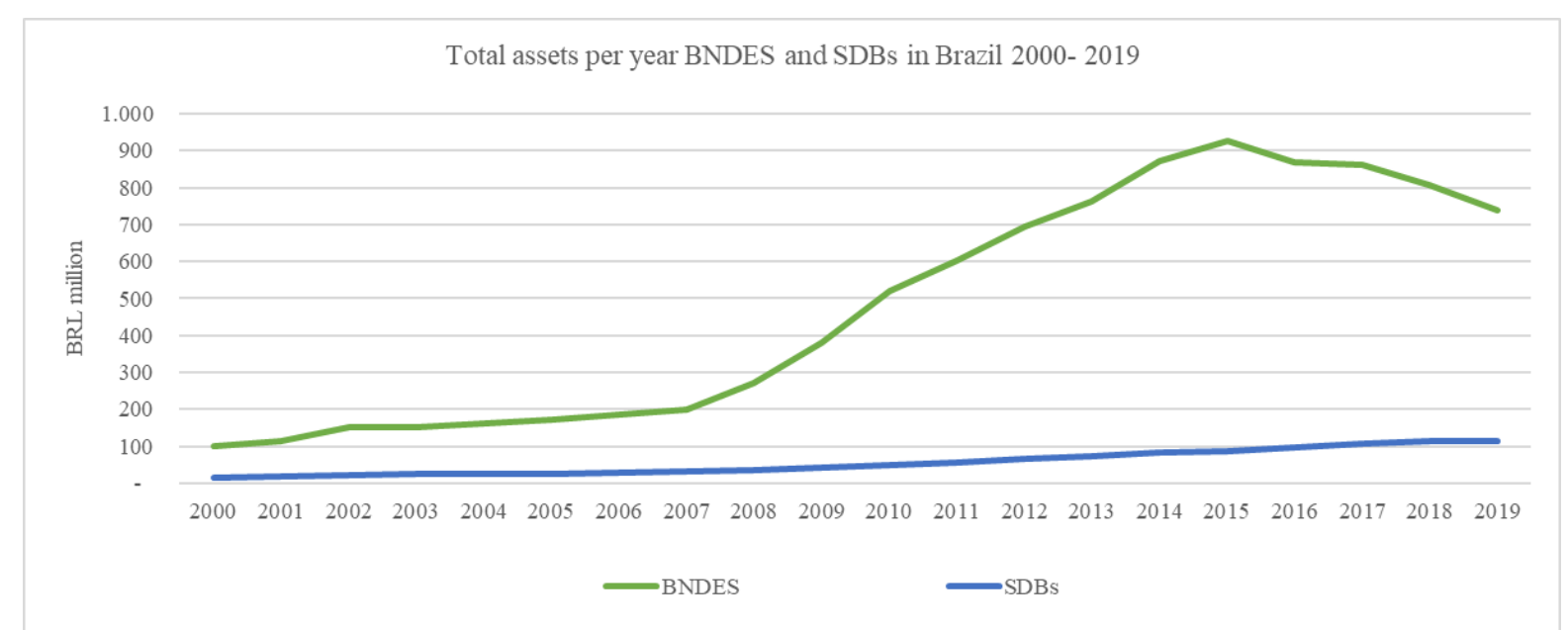

In terms of mandates and development instruments of the 21 SDBs in Brazil, it is possible to verify that the operational modalities vary a lot according to their size and region. According to Horn and Feil (2019), the main mandate modalities include: long-term credit for investment projects; financing small and medium-sized companies (SMEs), rural producers and production cooperatives; pure working capital; management of fiscal funds, normally used in operations with the municipal public sector to finance urban infrastructure projects. In addition to the financing modalities, Horn and Feil (2019) also mention activities of mobilizing economic agents in support of sectoral and regional development programs, such as the dissemination of information on credit lines and incentives. Blended finance instruments, such as mobilizing the private sector through public private partnerships, are also part of the scope of BNDES and SDBs. 
Regarding their governance, there is a growing concern to improve internal management practices highly recommended by the Brazilian Central Bank in order to prevent problems occurred in the 1990s. Among other structures, SDBs organizational structure includes the operation of technical committees, whose main objective is to ensure financial suitability and decision-making efficiency in internal activities (Horn and Feil, 2019). These committees are responsible for defining criteria for credit loans, risk management, accounting, among other practices. Most of the SDBs have boards of directors and directors appointed by the government of their controlling states and its composition must be approved by Brazilian central Bank.

Considering the data from 2019, there are also significant differences when it comes to equity and asset base among Brazilian SDB's. Banks with regional coverage, as BNB, BASA and BRDE, have a higher asset and equity base than state banks. As shown in Figure 8, BNB (Norwest Bank) appears as an outlier in terms of assets and equity (BRL 58.6 billion in assets and BRL 5.4 billion in equity), while BASA (Amazon) and BRDE (South Region) have similar sizes considering the asset-equity criteria- assets between BRL 15 and 20 million and equity between BRL 2 and 3 billion. The 18 state banks and development agencies have a maximum equity of BRL 1.8 billion and total assets between BRL 6 billion and BRL 8 million. BDMG (Minas Gerais state) stands out as the largest state development bank in Brazil. The state banks are quite diverse in terms of size: 11 development agencies have assets of up to BRL 600 million, 5 institutions have assets between BRL 1 billion and 3 billion and only 1 institution (BDMG) has assets greater than BRL 5 billion - Figure 9.

Another important feature of the Brazilian SDB seems to be the concentration of the system. Considering the total assets of the SDBs in $2019,90 \%$ of this amount is concentrated by four banks: BNB, BASA, BRDE and BDMG, three of them in the regional coverage and one with state coverage. 
Figure 8: Comparison between total assets and equity of SDBs (regional and state) in Brazil in 2019

Source: Authors elaboration from Central Bank of Brazil database, 2019.

Total assets $\mathrm{x}$ total equity Brazilian SDBs in 2019

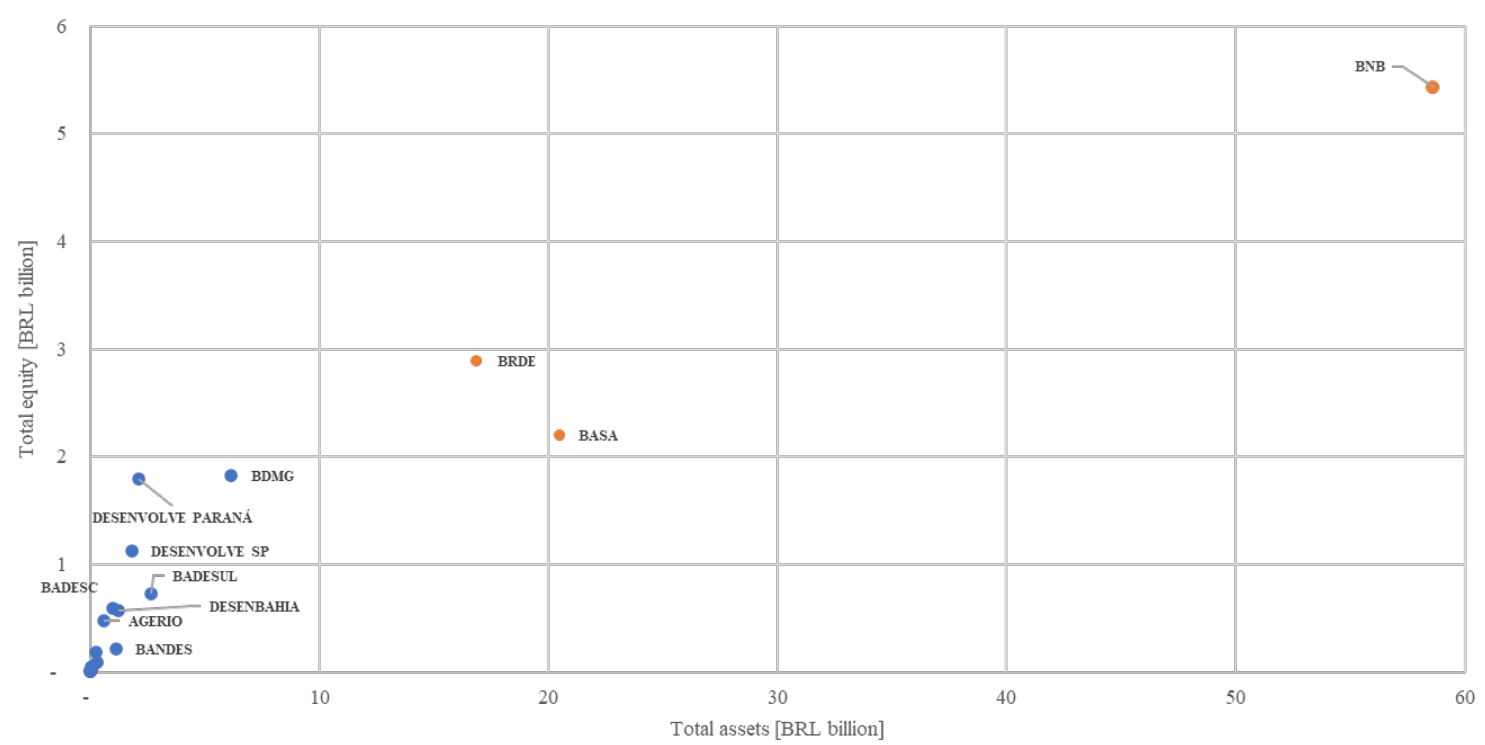

- Regional coverage $\quad$ - State coverage

Figure 9: Comparison between total assets and equity of states SDBs in Brazil in 2019 Source: Own elaboration from Central Bank of Brazil database.




According to Horn and Feil (2019), the significant size difference between SDBs in Brazil could be explained by the disparity participation of the controlling states in the national economy. In other words, the authors point out the tendency for the states with lowest participation in the Brazilian GDP to have the smallest SDBs, in terms of assets. For example, BDMG - the largest state development bank (as shown in Figure 9), operates in Minas Gerais, the third Brazilian state economy in terms of GDP ( $9.2 \%$ of the total country GDP). At the other extreme, the smallest state financial institution, Roraima Development Agency (AFERR), operates in a state with GDPs is equivalent to $0.2 \%$ of the national GDP. Some exceptions to this rule are the states of São Paulo and Rio de Janeiro, whose agencies do not correspond to the size of the economies.

As a last essential feature, the origin of funds is a fundamental issue to increase SDBs business and financial sustainability. According to Salviano Junior (2004) and Araújo and authors (2013), the majority of SDBs in Brazil is dependent on official resources, such as government funds, transfers from official institutions and own resources. Examples of government resources are constitutional funds with a focus on regional development, as the Northeast Constitutional Financing Fund (FNE) operated by BNB. Another source concerns the on-lending transfers from BNDES to SDBs. In fact, as discussed previously, the origin of the Brazilian SNF had in BNDES one of the main sources of funds, since SDBs were created to act in a complementary way to the national bank (Ferraz and Ramos, 2018). In addition to transfers from the BNDES, other official sources may come from institutions such as the Financier of Studies and Projects (FINEP), which is the administrator of the National Fund for Scientific and Technological Development (FNDCT), or specific funds such as the Coffee Economy Defense Fund (FUNCAFÉ) and the General Tourism Fund (FUNGETUR).

In the context of the fiscal restrictions faced by Brazilian states, governments funds has been a decreasing source of funding for state banks and development agencies, which have imposed strong incentives for them to make their operations more profitable, seeking a greater leverage in such a way that the results can be reverted to strengthen their financial position enabling a better access to funding in market conditions.

Partnerships with multilateral institutions (MDBs) also plays an important role in providing funding for development. It is possible to verify a path initiated by development banks at state and regional level, as BDMG and BRDE. These resources are often directed towards specific investments such as sustainability and financial inclusion, which reinforces the argument of the need to expand and integrate risk management with substantiality standards and methods for measuring and reporting impact in line with the requirements of funding institutions, as will be discussed further in this paper. 


\section{III - The Development system in Vietnam: local funds on the spot}

Located in East Asia, with China, Laos, Cambodia and Thailand as neighbours, Vietnam has been configuring itself as an emerging economy since its unification in 1974. It is the 14th country in the world in terms of population, with over 90 million inhabitants (Bulard, 2017; IHOLD, 2016; IMF, 2019) distributed into 58 provinces and five municipalities with provincial status (Can Tho, Ho Chi Minh City, Da Nang, Haiphong and Hanoi).

According to the International Monetary Fund (IMF) Country Report (2019), Vietnam has been experiencing a robust period of sustained development, with an average growth of $7 \%$ in the last 10 years. A set of factors is associated with this economic performance: marketoverflowing effects of Asian nations' growth, geopolitical circumstances, which led the country to effective trade agreements, and state inductive actions. Although the attraction of foreign industrial plants represented an increase in productivity and technological progress, it has itself posed new development challenges such as income inequality, environmental issues, education gaps and local development (World Bank, 2015).

The role of the banking system and development institutions has been increasing together with the country's recent evolution and is also influenced by a historical pivotal economic role played by the Vietnamese Government in the country's economy. Since 1988, the State Bank of Vietnam (SBV) accumulates functions of the country's central bank, financial regulatory agent and guardian of the monetary reserves. Simultaneously, state-owned commercial banks were restructured and had their role enhanced.

The state ownership of some commercial banks came from 1990's banking reform. Following the 1990 Ordinance on Banks, the SBV delegated its banking activities to four newly created state-owned commercial banks (SOCBs), each targeting a different segment of the economy: Vietnam Industrial and Commercial Bank - Vietinbank (industry and commerce); Bank for Agriculture and Rural Development - Agrinbank (agricultural and rural development); Bank for Foreign Trade of Vietnam - Vietcombank (international trade) and Bank for Investment and Development of Vietnam - BIDV(infrastructure).

According to the World Bank (2015), the 2008's crisis led to a major banking reform in the country with a step-by-step approach. One of these phases was the separation of development institutions and commercial banks (Tran, Ong and Weldon, 2015; Bulard, 2017; IMF, 2019). The development banks came from inside the commercial banks, as they used to perform development roles until the reforms. For example, social policies were implemented by the Bank for Agriculture and Rural Development until the creation of the Bank for Social Policies (Agribank, 2017). Several State Owned Commercial Banks (SOCB) are listed and are the bigger local-market players. Some of the institutions with promotional characteristics, after having been capitalized by larger banks, hold commercial portfolios either. 
A third set of development institutions operates at the subnational level- the Local Development Investment Funds - LDIF's. Founded after 2008, in the context of the financial crisis response in the major municipalities, the 18 LDIF's are regulated as non-financial institutions. Its background comes from the need to expand infrastructure and public goods investments - as sanitation, education, and social demand, by local credit institutions. According to AFD (2017), the local development fund model was chosen because of the numerous specific development challenges in municipalities, faced with the impacts of international financial crises. The government encouraged the decentralization of infrastructure investments at the provincial level: "[...] as commercial bank financing and bond issuance did not prove to be the appropriate solution for the Provincial People's Committees (PPC) during this period, the Local Development Investment Fund model was considered more appropriate in this context" (AFD, 2017).

In AFD database it is possible to identify different levels of finance development institutions in Vietnam, including at the national and subnational coverage: three national banks Vietnam Bank for Social Policies (VBSP), Vietnam Development Bank (VDB), Vietnam Russia Joint Venture Bank (VRB); and 18 local financing funds. Therefore, the resulting Vietnam development system combines a set of commercial banks with portfolios dedicated to specific economic sectors, with institutions focused on development, whether national or municipal coverage.

Figure 10: Vietnam development system

Source: Authors elaboration

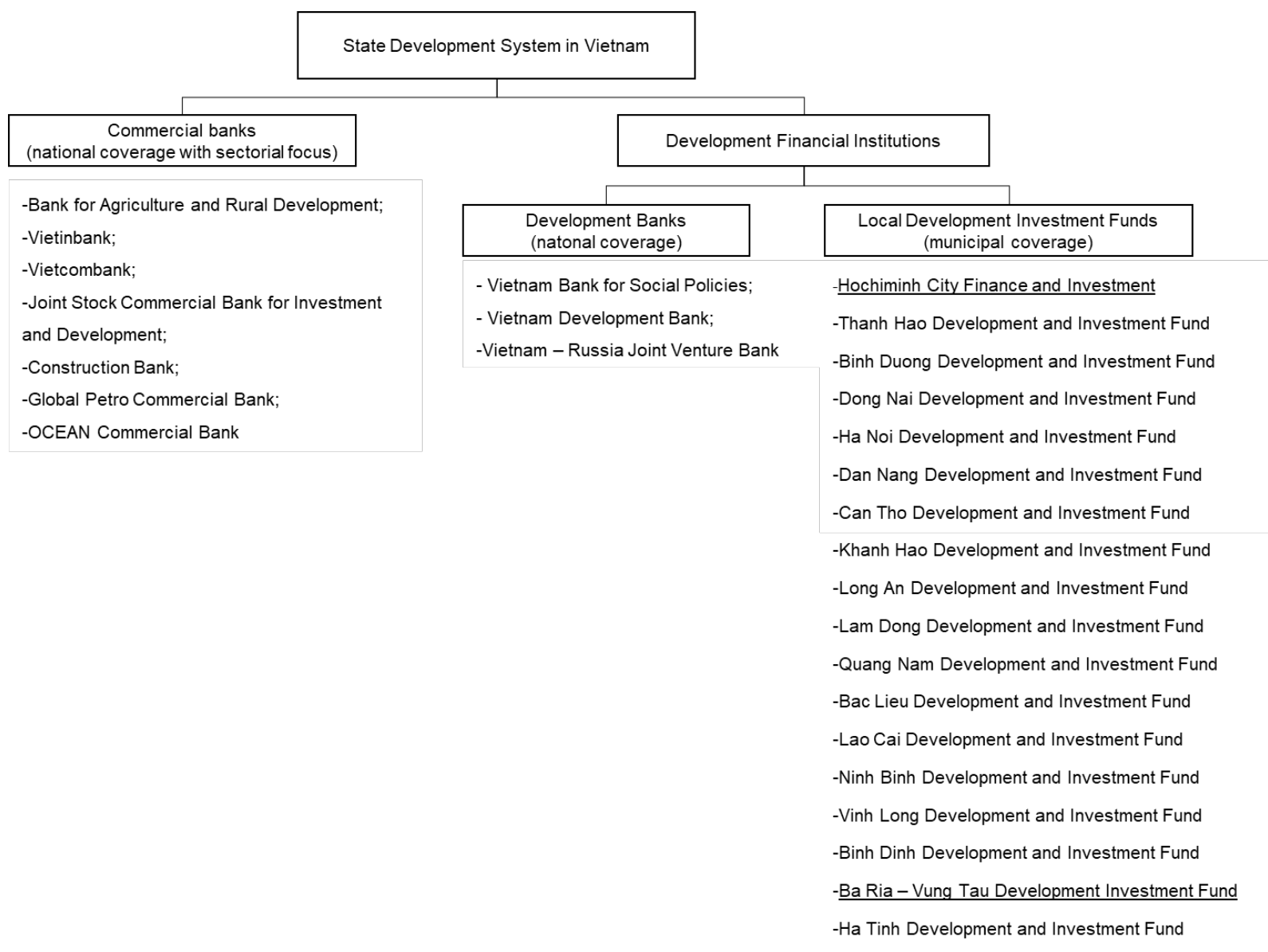


The Vietnamese national development system is relatively recent and is formed by this complex network of development institutions operating in a complementary way. Commercial banks with sectorial focus perform development functions by financing longterm investment while national development banks are physically present throughout the country's territory, with local branches through which they grant credit directly to local firms, fulfilling SDB's typical roles, with a certain degree of specialization in some development functions. Finally, the Local Development Investment Funds are focused on the support of improving local public services associated with a better infrastructure background.

At Vietnam provinces and its largest cities, national development banks and local funds act under complementary way. Because of the bank's dependency on limited treasury budget allocations and Official Development Assistance (ODA), Vietnam government decided to create local funds that were supported by MDB's in the beginning - World Bank and AFD (ESCAP, 2017). Because they were established to improve local investment demands with national and international resources sources, LDIFs are expected to operate as commercialoriented entities, selecting infrastructure projects that will generate sufficient financial returns (ESCAP, 2017). The model has been expanded to a total of 36 out of 63 provinces and it supportive legal framework has been updated consistently (ESCAP, 2018.According to ESCAP (2018) funding commitments were approximately \$144 million in February 2015 and each dollar invested from LDIFs has leveraged $\$ 1.73$ in investment.

Based on the most populous cities, Hochiminh City Finance and Investment (HFIC) is focused on infrastructure constraints and challenges in social services, environment and other economic sectors. Founded in 2010, it is a key investment instrument, which operates according to City People Committee's planning priorities (Cll, 2020). With the initial capital of 55 billion dongs and 100 billion dongs expected to be internalized by 2020 , HFIC funding comes from municipal bonds issuance, loans, and sponsorship (AFD, 2017; CBI, 2018; CEO Club of Vietnam, 2020; Cll, 2020).

Like HFIC, Hanoi Investment Fund (HNIF) in 2017 by the Hanoi People's Committee for the purposes of receiving budget capital, mobilizing medium term and long-term capital from organizations and individuals in the country and abroad. HNIF aims to enhance investments in projects and enterprises to develop Hanoi's infrastructure and improve its socioeconomic indicators. The fund aims to become a relevant capital mobilization channel in the city. With a charter capital by 220 million dollars (nearly , 5 billion dongs) the HADIF has expanded cooperation with local and foreign financial organizations and investors (Kiet, 2018).

As the other local investment funds, they work with both credit granting and equity. According World Bank (2012), the Ho Chi Minh City Investment Fund have been a playing a role model local fund in terms of internal policy and procedures for investment, infrastructure, social and environmental safeguards, and establishing partnerships with the private sector to increase its participation in financing municipal infrastructure in $\mathrm{Ho}$ Chi Minh City (World Bank, 2012; Cll, 2020). 
It is also important to consider that, although Local Development Funds are excepted from the regulatory control by Central Bank, they can be completely appropriate to international financing market procedures. The funds have legal status, charter capital and balance sheet. It is a relevant condition to obtain international resources, especially funds for green investments, which have been a relevant funding strategy.

According to SBV Key Statistical Ratios (SBV, 2020), in March 2020, the state banks represented more than $42 \%$ of the banking assets $-12,4$ trillion dong (VND). In equity, the state banks represent $25 \%$ ( 617 trillion VND). It is important to note that the State banks' group does not the municipality's funds. Although banks and local funds are constantly working to improve development, they act under different standards about the equity and assets relationship. For the banks, the financial leverage is the rule, since they get direct deposits. For the funds, created as channels to mobilize resources and applying them in other infrastructure funds, the leverage seems less important. Instead, the Vietnamese's local funds operate by channelling MDB's resources, establishing partnerships with private local funds and becoming shareholders of private enterprises (AFD, 2017; Kiet, 2018; Hà, 2019)2.

\section{IV - Comparing subnational development models: SDBs as a result of country's economic and political context}

The number, model and functions of development institutions in each country, whether at national or subnational levels, vary substantially, which makes it difficult to reproduce generalizations and patterns (Além et al., 2017). As emergent countries, both Brazil and Vietnam share significative development challenges. Bringing it in a nutshell, their architecture responds to the specific national development processes and the development of both financial systems. Several elements may be highlighted to allow a meaningful comparison between the two systems. Firstly, the state configuration. Brazilian SDBs have regional or state coverage, while Vietnamize funds work on municipal level.

\footnotetext{
${ }^{2}$ It is important to note that this research could not identify a common database for all local Vietnamese funds in terms of their equity and assets, which have prevented us from conducting a longitudinal analysis similar to the one that was done for the Brazilian case.
} 
A second comparison can be made by the year of establishment of the institutions at the subnational level. While Brazilian institutions followed the movement to create national development banks around the world, Vietnam's institutions were created more recently, mainly after the 2008 crisis. It is also important to note that while in Brazil there was a shrinking movement of these institutions regarding the 1990s liberal reforms, the significant presence of the state in its banking system suggests that the Vietnam's government didn't follow the liberal reforms from the 1990's onwards. In Vietnam case, nevertheless, the banking reform implied establishing Basel regulation rules to commercial banks and the emergency of the new development institutions.

The national development institutions also play different roles in both countries. In Vietnam, the national development banks coverage has branches in several cities acting as first-floor institutions. In contrast, BNDES, in Brazil, acts both as a second-floor institution, offering resources to the SDB's, and as a first-floor institution.

Regarding the relationship with national development system, Wruuck (2015), using the European model, explains that subnational public finance systems can be presented as vertical or horizontal ones. Além and authors (2017) explains that while some countries have more concentrated national development systems, with exists a strong and central role for an institution (normally the NDB) with all other funding institutions become subsidiaries in a vertical relation; in other models, horizontal ones, even if they have a prominent national institution, there are more specialized institutions to serve various segments and sectors. The German system, for example, can be conceptualized as a vertical system of development institutions, where the different levels (national and sub-national) are linked. For example, the NDB KfW provides financing to subnational institutions in Germany, and at the same time, German SDBs often play an active role in implementing policies. In the horizontal dimension, on the other hand, there is greater heterogeneity, since, although there is a main development bank at the national (or even multilateral) level, regional institutions (when they exist) would work independently, not necessarily adopting policies for similar economic sectors.

Brazil and Vietnam have different approaches in this sense. Brazil has a hybrid model, which mixes vertical and horizontal aspects, due to the strong presence of BNDES as a funding provider, together with the SDBs autonomy in the state or regional levels. On the other hand, Vietnam has an essentially horizontal model, due to local funds independency.

In the board below, we try to summarize the comparison between de two systems: 
Figure 11: Comparison between total assets and equity of states SDBs in Brazil in 2019 Source: own elaboration

\begin{tabular}{|c|c|c|}
\hline $\begin{array}{l}\text { National Development } \\
\text { System }\end{array}$ & Brazil & Vietnam \\
\hline $\begin{array}{l}\text { Type of subnational } \\
\text { institutions }\end{array}$ & $\begin{array}{l}\text { Multiple regional banks, Development } \\
\text { banks (regional and state banks) and } \\
\text { Development state agencies }\end{array}$ & $\begin{array}{l}\text { Local Development Investment Funds } \\
\text { (municipal coverage) }\end{array}$ \\
\hline Period of establishment & $\begin{array}{l}1960 \text { and reviewed after } 1996 \text { banking } \\
\text { restructuring program }\end{array}$ & After 2000 , especially after 2008 crises \\
\hline $\begin{array}{c}\text { Relationship with national } \\
\text { development system }\end{array}$ & Hybrid (predominantly vertical) & Horizontal \\
\hline Funding sources & $\begin{array}{l}\text { On-lending from BNDES, national funds, } \\
\text { subnational governments funds and } \\
\text { multilateral banks (all SDBs); national } \\
\text { or international bonds market (only } \\
\text { subnational public banks) }\end{array}$ & $\begin{array}{l}\text { Multilateral banks; equity stakes of } \\
\text { states banks; national and } \\
\text { international bonds markets }\end{array}$ \\
\hline $\begin{array}{l}\text { Under Central Bank } \\
\text { regulation/ Basel I or II }\end{array}$ & $\begin{array}{l}\text { All SDBs (including Development } \\
\text { Agencies) }\end{array}$ & $\begin{array}{l}\text { Local funds not subjected to Central } \\
\text { Bank regulations }\end{array}$ \\
\hline
\end{tabular}

This comparison, far from being exhaustive, demonstrates how a country's development system may present different aspects depending on its historical and economic context. However, these different formats do not prevent them from operating towards similar development goals in a pragmatic approach. In the next section, in terms of the recent sustainable finance frontier, the SDBs examples of Brazil and Vietnam demonstrates how such institutions can function as boosters of local impact. In addition to the Brazilian and Vietnamese examples, new subnational development banks in the United States with a clear mandate for green financing also reveals a new path for subnational institutions.

\section{V - The new sustainable finance paradigm and SDBs as the last mile institutions}

According to De Luna-Martinez and authors (2018), it will be necessary to mobilize trillions of dollars to achieve the Sustainable Development Goals (SDGs), fulfil the commitments of the Paris Agreement and meet the investment priorities listed in the Addis Ababa Action Agenda (AAAA). At the global level, the financing gap to achieve the SDGs was estimated to be US\$ 5 to 7 trillion, and roughly US\$2.5 - 3 trillion per year corresponds to the developing countries gap (UNCTAD, 2014). As the existing sources of financing are still insufficient to meet the development aspirations of the world, sustainable finance is part of a new paradigm, whose innovative and more effective instruments are urgent to mobilize capital, mainly for less developed regions and local context. The SDGs brings substantial changes in sustainable financing, including a much wider range of public and multilateral actors, with the presence of local institutions, and a greater volume of private financing (Shine and Campillo, 2016). It 
is not only a question of rethinking the volume of financing, but above all, ensuring that the financed projects have the right requirements to minimize negative impacts and enhance additionalities (Riaño and Barchiche, 2020).

The AAAA, in its turn, provides the blueprint to finance the goals addressed in the SDGs and considerably expands the diversity of actors involved in the mobilization of domestic and external financial resources. Combining the call made to development banks with the emphasis on local governments (Orliange, 2020), SDBs are positioned at the heart of AAAA. Following this direction, development finance could be maximized by strengthening a network of development banks at different levels - multilateral, regional, national and subnational (UNCTAD, 2016). According to the United Nations, banks at different levels could perform different functions and, at the same time, explore complementarities in order to benefit from combined regional efforts to act on projects in large countries (such as China and India) and also in small countries (like the Republic of Korea in the 1950s).

The SDBs may bring efficiency and effectiveness to the implementation of development programs as their local expertise directly contribute to a less costly and more agile credit analysis process and to a better identification and selection of projects, broadening the base of bankable ones. Acting in partnerships with larger national and multilateral institutions, SDB's helps them to better channel available financial and technical resources to promote local impact by adapting sophisticated governance and operational requirements to practical and pragmatic approaches that are suited to their local environment, acting as last mile institutions. That combination of strong partnerships, availability of resources and local expertise can create a much more prosperous space for closing the financial gap in terms of SDG implementation, as advocated by the AAAA.

Following the Brazilian and Vietnamese SDBs system discussed in this paper, it is possible to show with concrete examples of how the connection between SDBs and the sustainable financing agenda happens in practice. Some banks as the Development Bank of Minas Gerais (BDMG) in Brazil and Hochiminh City Finance and Investment (HFIC) in Vietnam, are incorporating 2030 Agenda premises into financial products, lending process and funding.

Regarding to the sustainability path in Brazil, BDMG was the first subnational institution to raise funds in the international market with a focus on sustainable operations in 2013. BDMG constituting itself as an institution with more than 58 years old (founded in 1962) operating in the 2nd largest Brazilian state in population and the country's third largest economy. As a financial and knowledge platform, the Bank provides not only credit lines, but it is engaged into project preparation and technical assistance. It is also the main credit supplier of Minas Gerais' pool of 853 municipalities.

The encouragement of sustainable development and the concern for future generations have increasingly been incorporated into BDMG's way of acting and internal policies over the years (BDMG, 2020a). In relation to the recent strategy of linking its portfolio to the goals of 2030 Agenda, a Framework was developed aiming financing investments that have clear and significant socio-environmental impacts and that contribute to the SDGs. The 
Sustainability Bonds Framework, also called SDG Framework ${ }^{3}$, certifies that part of the BDMG portfolio is in accordance with the Sustainability Bond Guidelines of 2018, which combines principles for green and social financing (BDMG, 2020b). In order to grant independence from the project eligibility process and ensure that the labelling process has positive additionalities, the SDG Framework was also subject to a Second Party Opinion (SPO), an external evaluation process by a specialized international company with a set of independent auditors.

Analysing the connection of the SDGs with BDMG financed portfolio, it is possible to verify the relationship with 13 of the 17 SDG goals and 28 of the 169 targets and some concrete finance experiences related to the SDGs, both in social and green investments.

Related to green investments, to substantially increase the share of renewable energies in the global energy matrix, BDMG is acting to foster SDG 7 (clean and affordable energy) and SDG 13 (action against global climate change). In 2019, in order to obtain resources to finance clean energy generation and energy efficiency projects, BDMG signed a contract with the European Investment Bank (EIB) that resulted in the raising of EUR 100 million. The credit line was intended to finance renewable energy generation projects - solar photovoltaic energy, small-scale hydroelectric energy and bioenergy plants - and energy efficiency, such as public lighting and efficiency in buildings and industries. Since the end of 2019, almost EUR 20 million has been invested in photovoltaic plant projects in low-development regions in Minas Gerais.

According to the Social Bons Principles, social categories aim directly to address or mitigate specific social issues and/or achieve positive social results, often for a well-defined vulnerable population (ICMA, 2020). BDMG examples of social investments consists in projects for municipalities accessible basic infrastructure (SDG 11), access to basic essential services - such as health (SDG 3) and education (SDG 4), job creation and programs designed to prevent and alleviate unemployment due to socioeconomic crises - including COVID-19 pandemic (SDG 8), gender financial inclusion (SDG 5), among others.

Vietnam banking deployment system can be seen as a carbon-dependent in progress to a more sustainable path (CBI, 2018). According the ASEAN Green Finance State of the Market (CBI, 2018), out of 47 public sector entitles green bonds potential issuers, six are Vietnamese. For the 2011-2020 period, the government approved the Vietnam Green Growth Strategy. On that regard, several institutions of the Vietnamese development system were considerate potential issuers: Vietnam Development Bank (VDB), Vietnam Bank for Social Policies (VBSP) and VietinBank. At the local level, some institutions have already issued bonds: Ho Chi Minh City (US\$ 23 MM, 2016) and Ba Ria Vung Tau Province (US\$ 4 MM, 2016). These green bonds financed projects of water management and climate adaptation (CBI, 2018).

\footnotetext{
${ }^{3}$ BDMG (2020). Sustainability Bonds Framework. Available at: https://www.bodmg.mg.gov.br/sustainable-bonds/
} 
In order to promote the 2030 Agenda, Hochiminh City Finance and Investment (HFIC), in a similar path to the Brazilian SDB BDMG, have certified its credit portfolio to be a climate bond issuer. In 2016, when the Vietnam Ministry of Finance approved a pilot project for subsovereign green bonds issue, the municipal People's Committee decided going to the market. Ho Chi Minh City Finance and Investment State Owned Company issued a VND 523.5 bn (USD23m) 15-year green bond with proceeds allocated to 11 projects related to the water, adaptation and infrastructure sectors (CBI, 2018).

In this sense, the partnership between multilateral banks and subnational institutions to create resource lines for sustainable purposes, such as Brazilian and Vietnamize examples mentioned above, is one of the possibilities for new international cooperation agreements cited in AAAA. While multilateral organizations have global reach, access to financial resources and technical expertise for projects of this nature, subnational banks have the capacity to direct resources to the regional or local context in development countries, implementing the global agenda on the ground.

In addition to the banks mentioned here, other countries are creating SDBs at regional or state level with a specific focus on sustainability. According to Coalition for Green Capital (CGC, 2017), several local specialized institutions were created in United States aiming work with green finance. The examples include the newly created development banks at the municipal or state level as the Connecticut Green Bank (founded in 2011), Hawaii Green Infrastructure Authority and NY Green Bank (both created in 2014) and Montgomery County Green Bank (2015). Other cases, such as the California Infrastructure and Economic Development Bank (IBank), created in the 1990s, include programs for energy and environmental needs, as programs for loans to municipalities, universities, schools and hospitals. 


\section{Conclusions}

The paper highlighted the potential of Subnational Development Banks (SDBs) as financial and knowledge platforms connecting global institutions and funds to local firms' and governments' needs. By doing so, we expect to demonstrate that these institutions may have a meaningful contribution in the global effort to make finance work for the necessary transition to a more sustainable development pattern and therefore should be empowered and better integrated to the global development community.

The examples of the Vietnamese and the Brazilian development systems illustrate several possibilities to ensure more resource mobilization to implement the 2030 Agenda. Although they are very different experiences, both provide an effective set of financial solutions to generate local impact. The two countries have also recently enforced their development systems by fostering sustainable frameworks and expanding the number of subnational entities. And they have been successful in terms of obtaining international resources to support the transition to a greener and more inclusive economy.

As mentioned before, this paper is part of a research agenda on how development institutions may better align themselves in the global effort to unleash the potential of more sustainable investments and economic practices.

We hope that it raises the interest of other scholars to keep investigating how subnational development banks may contribute to this major challenge. As future research questions, we believe that there is still a considerable amount of work to be performed in terms of better estimating the social, economic and environmental impacts of SDB's operations and, in this sense, have a clearer perspective regarding their level of addicionality. We also consider very important the building of reliable, comparable and public available databases on SDB's around the world, which would allow more comprehensive and robust analysis of this group of institutions. 


\section{References}

AFD - Agence Française de Developpement. (2017),

Evaluation Summary of Ho Chi Minh city Finance and Investment State-owned Company credit line (HFIC).

Available at:

https://www.afd.fr/en/ressource s/evaluation-summary-ho-chiminh-city-finance-andinvestment-state-ownedcompany-credit-line-hfic. [Accessed in August 2020]

Além, A. C., Madeira, R. F.; Martini, R. A. (2017),

Sistemas nacionais de fomento: experiências comparadas. Revista do BNDES, 47: 25l-256.

\section{Agribank - Vietnam Bank for Agriculture and Rural Development. (2017),}

Annual Report. Available at: https://www.agribank.com.vn/e $\mathrm{n} /$ ve-agribank. [Accessed in August 2020]

Araújo, V. L. de, Pires, M. J. de S., Silva, M. F. da, Castro, D. A. de. (2013),

O sistema brasileiro de instituições financeiras subnacionais para o desenvolvimento: um panorama. Nova Economia, 23(3): 579-618.

\section{BDMG - Banco de}

Desenvolvimento de Minas Gerais. (2020a),

2019 Sustainability

Report. Available at:

https://www.bdmg.mg.gov.br/re port/. [Accessed in August 2020]
BDMG - Banco de

Desenvolvimento de Minas

Gerais. (2020b),

Framework de títulos

sustentáveis, 2020b.

Available at:

https://www.bdmg.mg.gov.br/s ustainable-bonds/. [Accessed

in August 2020]

Brei, M., Schclarek, A. (2013),

Public bank lending in times of crisis. Journal of Financial Stability, 9(4): 820-830.

\section{Brei, M., Schclarek, A. (2018),}

The countercyclical behavior of national development banks in latin america and the caribbean. In: Griffith-Jones, S., Ocampo, J. A. (Ed.). The future of national development banks. Oxford University Press.

\section{Bruck, N. (2001),}

Development banking concepts and theory. In: ADFIAP-IDF. Principles and practices of development banking. Manila, Philippines: ADFIAP-IDF, 1: 9-39.

\section{Bulard, M. (2017),}

Vietnã, o polo industrial da vez. Le Monde Diplomatique Brasil, ed. 115. Available at: https://diplomatique.org.br/viet na-o-polo-industrial-da-vez. [Accessed in August 2020]

\section{Cavalcante, L. R. (2007),}

Seis personagens à procura de um autor: a inserção das agências de fomento e dos bancos de desenvolvimento no Sistema Financeiro no Brasil. Revista Desenbahia.

Available at:

http://www.desenbahia.ba.gov. br/publitao/arquivos/arquivos/1 314c568f7cb488e8427af9b64a7 dedb.pdf. [Accessed in June 2020]
CBI - Climate Bonds Initiative. (2018), ASEAN Green Finance - state of the market. Available at: https://www.climatebonds.net/fi les/files/ASEAN_GreenFin_SotM_ CBI_012019.pdf. [Accessed in August 2020]

CEO Club of Vietnam. (2020), Member Directory - HFIC.

Available at: http://ceoclubvietnam.com/me mbers/ho-chi-minh-cityfinance-and-investmentstate-owned/. [Accessed in August 2020]

\section{CII - Ho Chi Minh City} Infrastructure Investment Joint Stock Company. (2020), Founding Shareholders: HFIC. Available at: http://cii.com.vn/en/introductio $\mathrm{n} /$ founding-shareholders. [Accessed in August 2020]

\section{CGC - Coalition for Green} Capital. (2017)

Green Banks 101 \& Nevada Green Bank Study Results. One- day Workshop- July 27. Available at: https://www.nrel.gov/statelocal-tribal/basics-greenbanks.html. [Accessed in August 2020]

\section{Cunha, A. M., Prates, D. M.,} Carvalho, C. E. (2016),

O Sistema Nacional de Fomento: Formato Atual e Propostas de Reforma. Análise Econômica, 34 (65): 269-300.

Diamond, w. (1957),

Development Banks. Johns Hopkins Press. 
De Luna-Martínez, J., Vicente, C. L. (2012),

Global survey of development banks. The World Bank.

Available at:

https://papers.ssrn.com/sol3/pa pers.cfm?abstract_id=2006223.

[Accessed in June 2020]

De Luna-Martinez, J., Vicente, C. L., Arshad, A. B., Tatucu, R., Song, J., (2018),

2017 Survey of National development banks (English). Washington, D.C.: World Bank Group. Available at: http://documents.worldbank.or g/curated/en/9778215254380717 99/2017-Survey-of-Nationaldevelopment-banks [Accessed June 2020]

Ferroni, M. (2004),

Regional Public Goods: The Comparative Edge of Regional Development Banks. Paper prepared for a Conference on Financing for Development: Regional Challenges and the Regional Development Banks at the Institute for International Economics. Available at: https://www.piie.com/publicatio ns/papers/ferroni0202.pdf.

[Accessed June 2020]

Ferraz, J. C., Ramos, L. (2018), Inclusão financeira para a inserção produtiva de empresas de menor porte na América Latina: Inovações, determinantes e práticas de instituições financeiras do desenvolvimento. Informe regional, CEPAL. Available at: https://www.cepal.org/sites/def ault/files/document/files/docu mento_regional_version_en_e dicion.pdf. [Accessed in August 2020]
Gama Neto, R. B. (2011),

Plano Real, Privatização dos

Bancos Estaduais e Reeleição.

Revista Brasileira de Ciências

Sociais, 26 (77): 129-150.

Griffith-Jones, S., Ocampo, J.

A., Rezende, F., Schclarek, A, and Brei, M. (2018),

The Future of National

Development Banks:

Introduction. In: Griffith-Jones, S. and Ocampo, J. A. (Eds.). (2018).

The future of national

development banks. Oxford

University Press.

Hakenes, H.; Schnabel, I. (2010), The Threat of Capital Drain: A Rationale for Regional Public Banks? Journal of Institutional and Theoretical Economics, 166 (4): 662-689.

Hà, H. T. (2019),

Hanoi development fund looks to more efficient operation. Vietnam Plus. Available at: https://en.vietnamplus.vn/hanoi -development-fund-looks-tomore-efficientoperation/152587.vnp. [Accessed in August 2020]

Horn, C. H., Feil, F. (2019), Instituições financeiras de desenvolvimento regional e os desafios do Sistema Nacional de Fomento. Economia e Sociedade, 28(1), 227-254.

\section{IHOLD Brasil. (2016),}

Vietnã: o novo milagre econômico? Available at: https://ptbr.ihodl.com/economics/201609-03/vietna-o-novo-milagreeconomico/. [Accessed in August 2020]
IMF - International Monetary Fund. (2019), Anex IV. IFM Country Report No. 19/235. Vietnam. Available at: www.imf.org/en/countries/vnm. [Accessed in August 2020]

Kiet, A. (2018),

Hanoi sets up new US\$220-

billion development investment fund. Hanoi Times/Investment. Available at: http://hanoitimes.vn/hanoisets-up-new-us220-billiondevelopment-investmentfund-5679.html. [Accessed in August 2020]

La Porta, R., Lopez-De-Silanes, F., Shleifer, A. (2002), Government ownership of banks. The Journal of Finance, 57 (1): 265-301.

Levy-Yeyati, E., Micco, A. and Panizza, U. (2004),

Should the Government Be in the Banking Business? The Role of State-Owned and Development Banks. IDB Working Paper. Available at: https://publications.iadb.org/en /publication/shouldgovernment-be-bankingbusiness-role-state-ownedand-development-banks [Accessed June 2020]

Mazzucato, M., Penna, C. (2016), Beyond Market Failures: The Market Creating and Shaping Roles of State Investment Banks. Journal of Economic Policy Reform, 19 (4): 305-326.

Orliange, P. A., (2020), From poverty reduction to global challenges, a new horizon for international development cooperation? Revista Brasileira de Política Internacional, 63(2): 1-26. 
Riaño, M. A., Barchiche, D. (2020),

Financing the 2030 Agenda for Sustainable Development: prerequisites, and opportunities for the post-Covid-19 crisis. IDDRI issue brief. Available at: https://www.iddri.org/sites/defa ult/files/PDF/Publications/Catalo gue\%20lddri/D\%C3\%A9cryptage /202005-IB03202030\%20agenda_0.pdf. [Accessed in August 2020]

Salviano Junior, C. (2004), Bancos estaduais: dos problemas crônicos ao PROES. Banco Central do Brasil. Available at: https://www.bcb.gov.br/htms/p ublic/BancosEstaduais/livro_ba ncos_estaduais.pdf. [Accessed in June 2020]

\section{SBV - State Bank}

\section{of Vietnam.(2018),}

SBV revises Establishment and Operation License of VRB.

Available at:

https://www.sbv.gov.vn/webcen ter/portal/en/home/sbv/news. [Accessed in August 2020]

\section{SBV - State Bank} of Vietnam. (2020),

Data ratios 2020. Available at: https://www.sbv.gov.vn/webcen ter/portal/en/home/sbv/news. [Accessed in August 2020]

\section{Shelepov, A. (2017),}

New and Traditional Multilateral Development Banks: Current and Potential Cooperation. International Organisations Research Journal, 12(1).
Shine, T., Campillo, G. (2016), The role of development finance in climate action post-2015. OECD Development Co-operation Working Papers, n. 31, OECD Publishing, Paris.

\section{Stiglitz, J. (1994),}

The role of the state in financial markets. Washington, D.C.: The World Bank.

\section{Studart, $\mathbf{R}$.,} Gallagher, K. P. (2016), Infrastructure for sustainable development: the role of national development banks. GEGI Policy Brief 007.

\section{Torres, E., Zeidan, R. (2016),} The life-cycle of national development banks: The experience of Brazil's BNDES. The Quarterly Review of Economics and Finance, 62: 97-104.

\section{UNCTAD - United Nations \\ Conference on Trade and Development. (2014),}

World investment report 2014: Investing in the SDGs: An action plan. United Nations publication.

\section{UNCTAD - United Nations Conference on Trade and Development. (2016),}

The Role of Development Banks. In: Promoting growth and sustainable development in the South. United Nations publication (UNCTAD/GDS/ECIDC/2016/1).
UN-DESA - United Nations Department of Economic and Social Affairs. (2005), Rethinking the role of national development banks. New York: UN-DESA.

\section{Wruuck, P. (2015),}

Promoting investment and growth: The role of development banks in Europe. Deutsche Bank Research.

\section{World Bank. (2012),}

ICR Review Independent Evaluation Group for Ho Chi Minh City Investment Fund For Urban Development Project (disclosure authorized).

Available at: https://projects.worldbank.org/e n/projects-operations/projectdetail/P104848. [Accessed in August 2020]

\section{World Bank. (2015),}

Taking stock: un update on Vietnam's recent economic developments. (public disclosure authorized). Available at: www.worlbank.org.vn. [Accessed in August 2020]

Xu, J., Ren, X., Wu, X. (2019), Mapping development finance institutions worldwide: Definitions, rationales and varieties. New Structural Economics Development Financing Report. 



\section{What is AFD?}

The Agence Française de Développement (AFD) Group is a public entity which finances, supports and expedites transitions toward a more just and sustainable world. As a French overseas aid platform for sustainable development and investment, we and our partners create shared solutions, with and for the people of the global South.

Active in more than 4,000 projects in the French overseas departments and some 115 countries, our teams strive to promote health, education and gender equality, and are working to protect our common resources - peace, education, health, biodiversity and a stable climate. It's our way of honoring the commitment France and the French people have made to fulfill the Sustainable Development Goals.

Towards a world in common.

Publication Director Rémy Rioux Editor-in-Chief Thomas Melonio

Legal deposit 4th quarter 2020

ISSN 2492 - 2846 C AFD

Graphic design MeMo, Juliegilles, D. Cazeils Layout AFD

Printed by the AFD reprography service 